\title{
酸化マグネシウム錠の自動錠剤分包機ローターカセット内での 吸湿が製剤の安定性に及ぼす影響
}

\author{
松尾泰佑 ${ }^{* 1}$, 富田 隆 ${ }^{2}$, 工藤賢三 ${ }^{2,3}$, 佐塚泰之 ${ }^{1}$ \\ 岩手医科大学薬学部創剂学講座 ${ }^{1}$, 臨床薬剤学講座 ${ }^{2}$, 岩手医科大学附属病院薬剂部 ${ }^{3}$
}

\section{Effects of Moisture Absorption of Magnesium Oxide Tablets Stored in Rotor Cassettes on Formulation Stability}

\author{
Taisuke Matsuo*1, Takashi Tomita ${ }^{2}$, Kenzo Kudo ${ }^{2,3}$ and Yasuyuki Sadzuka ${ }^{1}$ \\ Department of Advanced Pharmaceutics ${ }^{1}$, \\ Department of Clinical Pharmaceutics and Pharmacy Practice, School of Pharmacy ${ }^{2}$, Iwate Medical University, \\ Department of Clinical Pharmaceutics, School of Pharmacy, Iwate Medical University ${ }^{3}$ \\ $\left[\begin{array}{l}\text { Received December 27, } 2017 \\ \text { Accepted March 3, } 2018\end{array}\right]$
}

Magnesium oxide tablets are commonly used as antacids or laxatives. They are mainly formulated for the elderly to relieve constipation. Although these tablets normally undergo rapid disintegration, moisture absorption causes an increase of the disintegration time. However, magnesium oxide tablets are sometimes dispensed in a one-dose package. In this study, we examined the effects of moisture absorption of a magnesium oxide tablet stored in rotor cassettes on formulation stability. The tablets were stored in rotor cassettes under $55 \% \mathrm{RH}$ or $75 \% \mathrm{RH}$ conditions for 7 days. These tablets were analyzed for weight, hardness, disintegration time, dissolution test, friability, and breakage after storage in rotor cassettes. Although the weight increased in a humidity-dependent manner, moisture absorption of the tablets significantly decreased when a desiccating agent was used. In contrast, the other tablet properties showed little difference. We further examined whether moisture absorption of the tablets stored in rotor cassettes caused deterioration in quality when stored in a one-dose package under the condition of $75 \% \mathrm{RH}$. Our results show that moisture absorption of the tablets enhanced hardness and delayed disintegration time. This delay in disintegration time of magnesium oxide tablets increases the risk of choking on a tablet and reduces the compliance of patients who have difficulty swallowing tablets. In conclusion, we demonstrated that moisture absorption affects the quality of magnesium oxide tablets while the preservation after one-dose packaging. It is important for pharmacists to carefully consider the effects of moisture absorption of hygroscopic tablets stored in rotor cassettes, when tablet packaging machines are used.

Key words — tablet packaging machine, magnesium oxide, one dose packaging, moisture absorption, disintegration, dissolution

\section{緒 言}

酸化マグネシウムは制酸薬・緩下薬として汎用 されているが，古くは原末が用いられていたこと から, 無機化合物特有の味や口腔内への残存によ る不快感が低コンプライアンスの原因となってい た.この問題を解消するために後発医薬品として 酸化マグネシウム錠が開発され，現在ではその使
用が増加している. ${ }^{1,2}$ 各社から販売されている酸 化マグネシウム錠は添加剤が異なるものの, 高い 崩壊性を有する製品が多い。酸化マグネシウム製 剂であるマグミット® ${ }^{\circledR}$ 錠 $^{3)}$ は崩壊時間が短いこと から, 少量の水とともに服用することにより口中 で崩壊し, 嚥下困難な患者でも服用しやすい利点 をもつ.しかし, 酸化マグネシウムは高い吸湿性 のため, 酸化マグネシウム錠を無包装状態で保存

\footnotetext{
*T028-3694 岩手県紫波郡矢巾町西徳田2-1-1
} 
した際には吸湿により崩壊時間が著しく延長する 問題がある. ${ }^{4)}$ そのため, 一包化保存においても 品質の低下を引き起こす. ${ }^{5}$

医薬品の一包化は, 薬の飲み間違いや飲久忘れ を防ぐうえで有効な手段であることから，多くの 病院や薬局では全自動錠剂分包機が導入されてい る. ${ }^{6-8)}$ 全自動錠剤分包機は調剂時間を短縮させ，薬 剤師業務の効率化や患者の待ち時間の減少につな がるもののローターカセット内に医薬品を無包装 状態として充填するため, 吸湿性が高い医薬品は ローターカセット内での吸湿により, 錠剂の品質 が低下する恐れがある．特に, 一包化調剂後にロー ターカセットに残った錠剤は, 次の調剤まで外気 に曝されることになる，医薬品の吸湿に影響する と考えられるローターカセット内の湿度は, 調剤 室の湿度と同程度またはそれ以上の值を示すこと が明らかにされており，調剤室湿度は 40～70\% RH と定められていることから，ローターカセット 内の湿度もこれに伴い変動すると予測される. ${ }^{9,10)}$

本研究では, 酸化マグネシウム錠をローターカ セット内で保存した際に生じる吸湿が錠剤の安定 性に及ほす影響を明らかにするために，55％ RH もしくは $75 \%$ RH で 1 週間保存した際の質量変 化および安定性変化を調べた，さらに，ローター カセット内に扔ける吸湿が一包化調剂後の長期保 存時の安定性に及ぼす影響を評価した。

\section{方 法}

\section{1. 酸化マグネシウム錠の保存方法}

酸化マグネシウム錠は，マグミット®錠 $330 \mathrm{mg}$ (協和化学工業(株), 香川, ロット 16L302, 17H047, 17H056）を使用した。ローターカセットは，ロー タリー式全自動錠剂分包機 YS-TR-250FDS（湯山 製作所(株)，大阪）に対応したSS 型を用い, 各ロー ターカセットに酸化マグネシウム錠を 50 錠ずつ 保存した。保存は, 室温 $\left(26.5 \pm 2^{\circ} \mathrm{C}\right)$, 湿度 55 $\pm 5 \%$ RHもしくは $75 \pm 5 \%$ RHで 7 日間行った。 また，ローターカセットは乾燥剤を設置すること が可能であるが，適切に乾燥剤が使用されていな い場合を想定し, 乾燥剤の有無についても検討し た。なお, 温度は 0,7 日目の 9〜12 時に測定した。

\section{2. 酸化マグネシウム錠の安定性評価}

ローターカセット内で酸化マグネシウム錠を 7 日間保存した後, 以下の 6 項目について評価した。 質量，崩壊時間，硬度，溶出率は上述した 3 ロッ トの平均とし，摩損度および自動錠剂分包機によ る分包後の質量減少率はロット16L302を用いた。

\section{(1) 質量}

酸化マグネシウム錠の質量は, 高精度電子天秤 を用いて 1 錠ごとの質量を測定し, 保存前の質量 に対する保存後の質量変化率を算出した．50 錠 の質量変化率の平均を 1 ロット当たりの変化と し， 3 ロットの平均を算出した。

\section{(2) 硬度}

硬度はモンサント型錠剂硬度計（富士理化工業 (株)，大阪）を用いて，1ロット当たり 6 錠計測 した６錠の平均を 1 ロット当たりの硬度とし， 3 ロットの平均を算出した.

\section{（3）崩壊試験}

崩壊試験器（NT-40HS，富山産業(株), 大阪） を用いて, 第 17 改正日本薬局方の一般試験法「崩 壊試験法」に準じて行った。試験液は水（温度： $\left.37 \pm 2^{\circ} \mathrm{C}\right)$ を用い, $30 \mathrm{rpm}$ で行い, 完全に崩壊す るまでの時間を測定した． 6 錠の平均を 1 ロット当 たりの崩壊時間とし，3 ロットの平均を算出した。

\section{（4）溶出試験}

溶出試験器 (NTR-3000, 富山産業(株)) を用いて, 第 17 改正日本薬局方の一般試験法「溶出試験法」 のパドル法に準じて行った。試験液は溶出試験第 1 液（ $\mathrm{pH} 1.2$, 温度 : $37 \pm 0.5^{\circ} \mathrm{C} ）$ を $500 \mathrm{~mL}$ 用い, $50 \mathrm{rpm}$ で行った $15 ， 30 ， 60 ， 120$ 分後の溶出量を 日本薬局方・キレート滴定にて測定し, 以下の計 算式により酸化マグネシウム量を算出した.

$\lceil 0.05 \mathrm{~mol} / \mathrm{L}$ エチレンジアミン四酢酸二水素二 ナトリウム液 $1 \mathrm{~mL}=2.015 \mathrm{mg}$ 酸化マグネシウム」 また, 3 錠の平均を 1 ロット当たりの溶出率とし, 3 ロットの平均を算出した。

\section{（5）摩損度}

錠剂摩損度試験器（TFT-120, 富山産業(株)） を用いて, 第 17 改正日本薬局方の参考情報「錠 剤の摩損度試験法」に準じて行った。 1 回 $6.5 \mathrm{~g}$ に相当する量を用いてドラムを $25 \pm 1 \mathrm{rpm}$ で 100 回転させた時の質量減少率を算出し, 日本薬 
局方において「望ましい」とされる $1.0 \%$ 以下と なるか確認した

\section{（6）自動分包機による分包時の錠剤破損の有無}

ロータリー式全自動錠郕分包機 YS-TR-250FDS を用いて，酸化マグネシウム錠 $330 \mathrm{mg}$ を分包し た．酸化マグネシウム錠は緩下薬として使用する 際，1 日 $2 \mathrm{~g}$ を 2 3 回に分けて服用するため, 3 回服用時を想定し 2 錠 $(660 \mathrm{mg}) /$ 包とした. 一包 化は，一般的な一包化シートであるセロハンポリ エチレンラミネート紙（薄口 $20 \mu \mathrm{m}$ ；湯山製作所 (株)）を使用した。ローターカセットは最上部 （9段目）に設置し，分包後の錠剤破損の有無を 目視で確認するとともに写真撮影および質量減少 率を調べた。

\section{3. ローターカセット内での酸化マグネシウム錠 の吸湿が一包化後の安定性に及ぼす影響}

酸化マグネシウム錠 $330 \mathrm{mg}$ はロット16L302 を用い, $75 \pm 5 \% \mathrm{RH}$ 環境下であらかじめ $1.4 \%$ （55\% RH 保存相当）もしくは 4.1\%（75\% RH 保 存相当) 吸湿させ, 2 錠/包で一包化した. 室温 (26.1 $\left.\pm 2.4{ }^{\circ} \mathrm{C}\right), 75 \% \pm 5 \% \mathrm{RH}$ 環境下で 8 週間保存 した時の質量変化 $(n=7)$, 硬度 $(n=5)$, 崩壊 時間（ $\mathrm{n}=5 ）$ および溶出率 $(\mathrm{n}=3)$ を上述した 方法で測定した。なお，温度は解析日の 9 12 時 に測定した。

\section{4. ローターカセット内の位置が吸湿に及ぼす影響} 酸化マグネシウム錠 $330 \mathrm{mg}$ （ロット 16L302） を上述したローターカセット SS 型に 400 錠入れ， 湿度 $75 \pm 5 \%$ RH で 28 日間保存した。その後, カセット内の上部, 中部, 下部の錠剤の質量を各 20 錠ずつ測定し，質量増加率を算出した.

\section{5. 統計解析}

測定結果は, 平均 \pm 標準偏差で示した，統計 解析は student's $t$-test で行い, $P<0.05$ を統計学的 に有意差ありとした。さらに、ローターカセット 内の位置における質量変化は, One-way ANOVA によって 3 群 (上部, 中部, 下部) での比較を行 い，有意差があることを再検証した．

\section{結果}

\section{1. ローターカセット内での保存が酸化マグネシ ウム錠の安定性に及ぼす影響}

（1）質量変化（図 1）

酸化マグネシウム錠 $330 \mathrm{mg}$ をローターカセッ 卜内に 50 錠入れ，湿度 $55 \%$ RH もしくは $75 \%$ RH で 7 日間保存した時の質量変化を調べた. $55 \%$ RH 保存時には $1.8 \%$ の増加だったのに対し， 75\% RH では 4.6\%質量が増加した（図 1)。一方， $75 \%$ RH 保存時にローターカセット内に乾燥剤を 設置した際には，質量増加率が $2.7 \%$ であり，乾 燥剂未使用時と比べて約 $40 \%$ 抑制された（図 1）. また，この時平均吸湿量の 2 倍以上吸湿していた 錠剤数は, 3 ロット 150 個中 3 錠 (55\% RH 保存), 0 錠（75\% RH 保存)，5 錠（75\% RH + 乾燥剂保 存）とわずかであったが，それらは外気に曝され る可能性の高い排出口付近に保存された錠剤で あった（結果は示してない）。

（2）硬度・崩壊時間・溶出性の変化（図 2）

ローターカセット内での保存が酸化マグネシウ ム錠の安定性に及ぼす影響を明らかにするため に, 硬度, 崩壊時間および溶出率を測定した。そ の結果，硬度は，いずれの保存条件においても開 封直後と変化しなかった（図 2A）。また，75\% RH 保存時における崩壊時間は開封直後の錠剤よ りも約 1 秒の延長が確認されたもののほとんど影 響しなかった（図 2B）。溶出率は, $75 \% \mathrm{RH}$ 保存

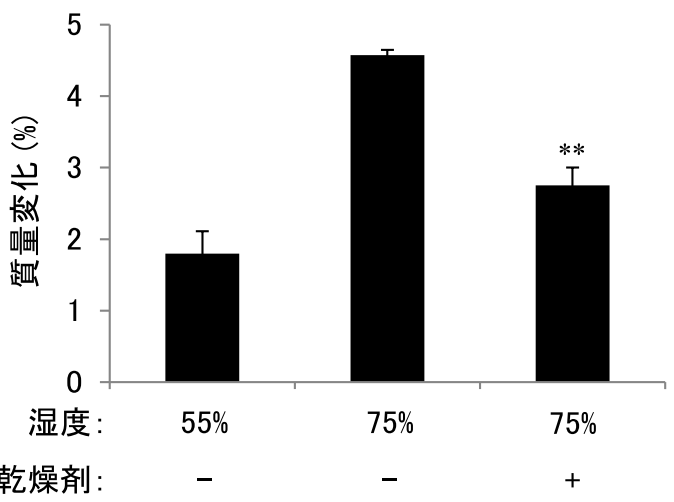

图1 ローターカセット内で保存した酸化マグネシ ウム錠の質量変化

各点は平均 \pm 標準偏差を示す。 $* * P<0.01$ vs $75 \%$ RH（乾燥 剂 $(-)$ ) 保存 (Student's $t$-test). 
A

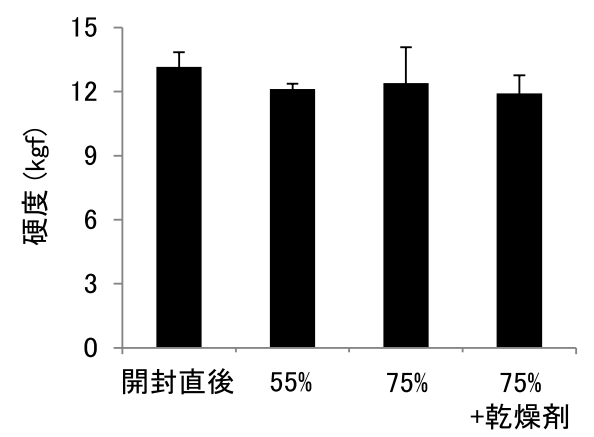

B

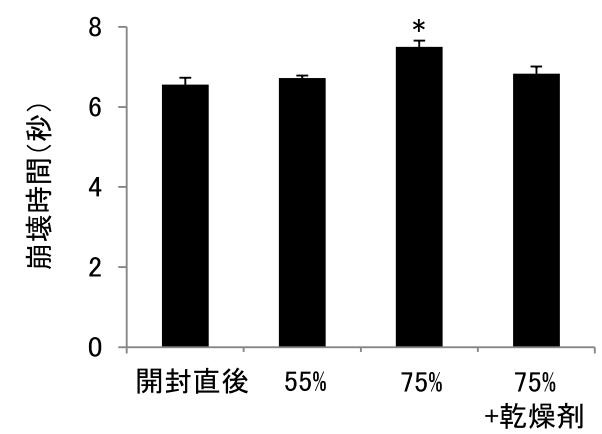

C

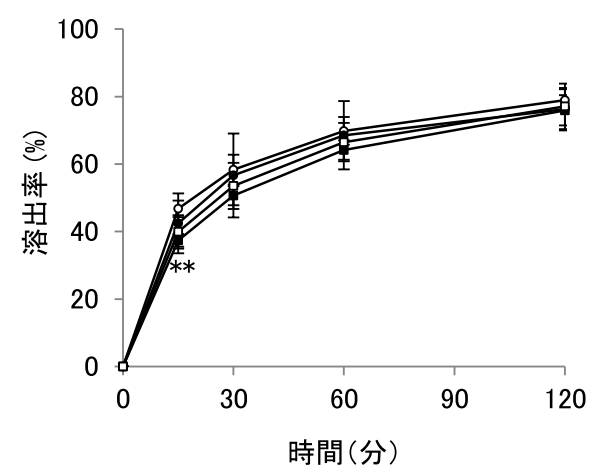

図2ローターカセット内で保存した酸化マグネシ ウム錠の安定性変化

A : 硬度, B : 崩壊時間, C : 溶出率. $\bigcirc$ 開封直後, $55 \%$ RH 保存, $\square 75 \%$ RH 保存, $\square 75 \%$ RH 保存 + 乾燥剂。各点は 平均 \pm 標準偏差を示す. $* P<0.05, * * P<0.01 \mathrm{vs}$ 開封直後 の錠剂 (Student's $t$-test).

時では 15 分後の溶出率が約 $20 \%$ 低下したが，そ の差は経時的に縮小され 120 分後には開封直後と 同程度となった（図 2C）.

（3）自動錠剂分包機による酸化マグネシウム錠 の破損および摩損度変化（図 3）

ローターカセット内で保存した酸化マグネシウ ム錠の一包化の可否を評価するために，自動錠剂 分包機の最上段にローターカセットを設置して一 包化を行った。その結果，いずれの保存条件にお

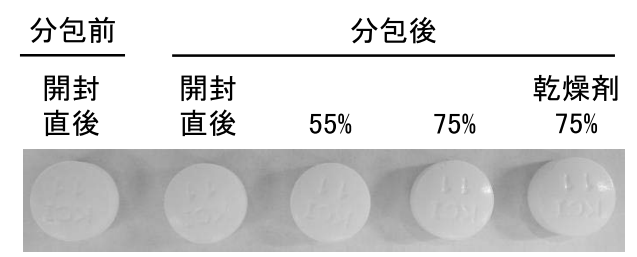

B

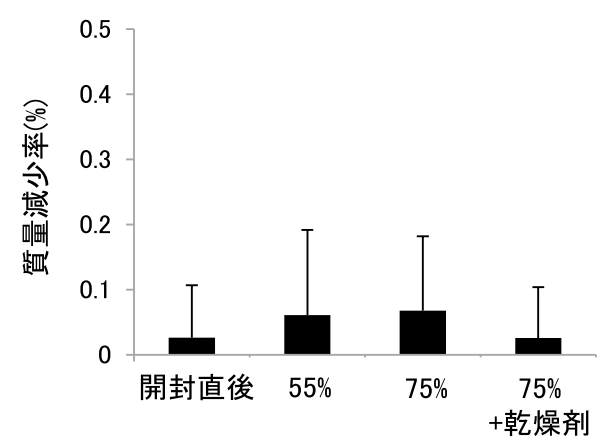

C

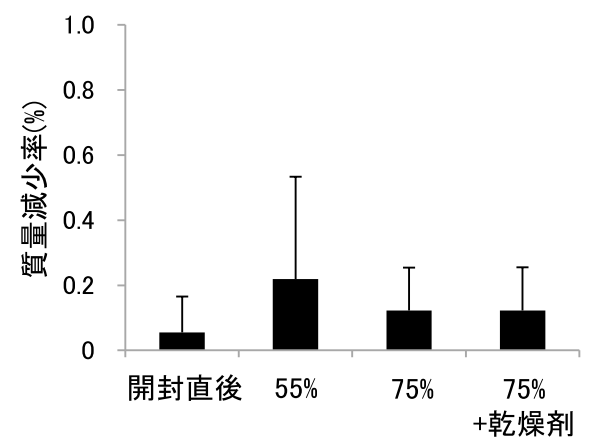

図３＼cjkstart自動錠剂分包機による錠剤破損および摩損度 試験

$\mathrm{A}$ ：外観変化, B：分包後の質量減少率, C : 摩損度試験によ る質量減少率. 各点は平均 \pm 標準偏差を示す.

いても分包時の破損は肉眼では認められず，質量 も変化しなかった（図3A，B）。また，摩損度試 験を行ったところ, 100 回転での質量減少率は全 て1.0\%以下であった（図3C）。

\section{2. ローターカセット内での吸湿が一包化保存後 の安定性に及ぼす影響（図 4, 5）}

次に，ローターカセットで 1 週間保存した酸化 マグネシウム錠の吸湿が一包化保存後の安定性に 及ぼす影響を解析した。酸化マグネシウム錠 (ロッ 卜16L302）をローターカセット内で 1 週間保存 した際の吸湿は $55 \%$ RH では $1.4 \pm 0.6 \% ， 75 \%$ RH では $4.5 \pm 0.8 \%$ であった（結果は示していな い）。そこで，あらかじめ $1.4 \pm 0.1 \% （ 55 \% \mathrm{RH}$ 


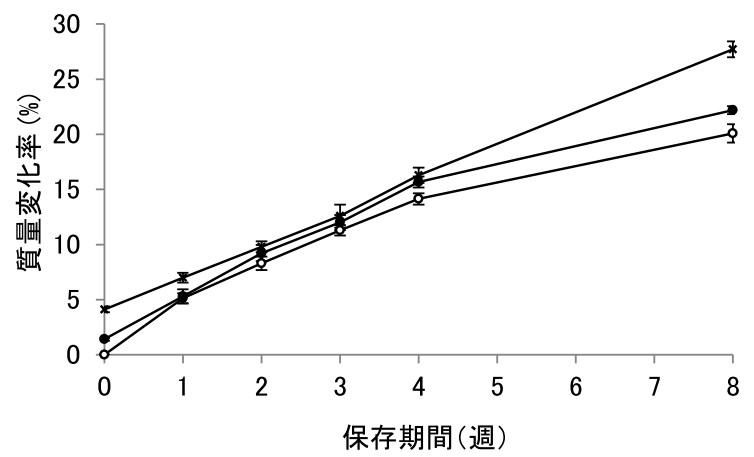

B
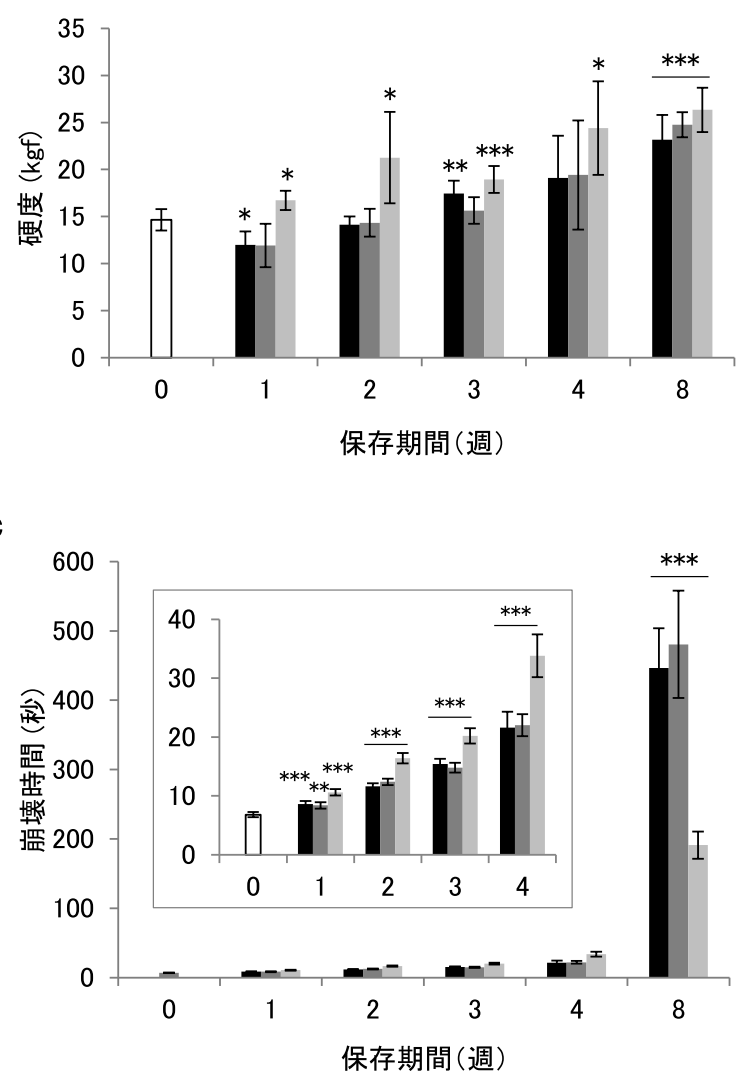

図 4 一包化前の吸湿による酸化マグネシウム錠の 安定性変化

A : 質量変化率, $\bigcirc$ 開封直後に一包化, 1.4\%吸湿後に一包化, $\times 4.1 \%$ 吸湿後に一包化. B : 硬度, C : 崩壊時間, $\square$ 開封直後,

開封直後に一包化, $\square 1.4 \%$ 吸湿後に一包化, $\square 4.1 \%$ 吸湿 後に一包化. C の $0 \sim 4$ 週間保存時の崩壊時間は拡大して示し ている. 各点は平均 \pm 標準偏差を示す. $* P<0.05, * * P<0.01$, $* * * P<0.001 \mathrm{vs}$ 開封直後の錠剂 (Student's $t$-test).

保存相当）もしくは $4.1 \pm 0.3 \% （ 75 \%$ RH 保存 相当)吸湿させた酸化マグネシウム錠を一包化し, 湿度 $75 \%$ RH で 8 週間保存した時の安定性を評 価した。その結果，一包化前の質量差は 1 週間後 から縮小されたものの，完全にはなくならなかっ た（図 4A）.

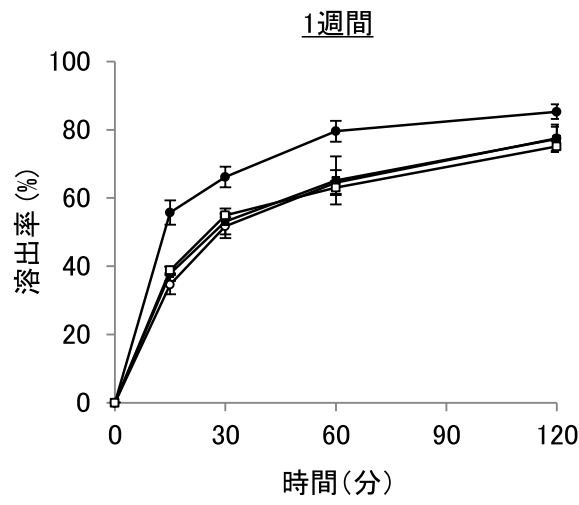

B

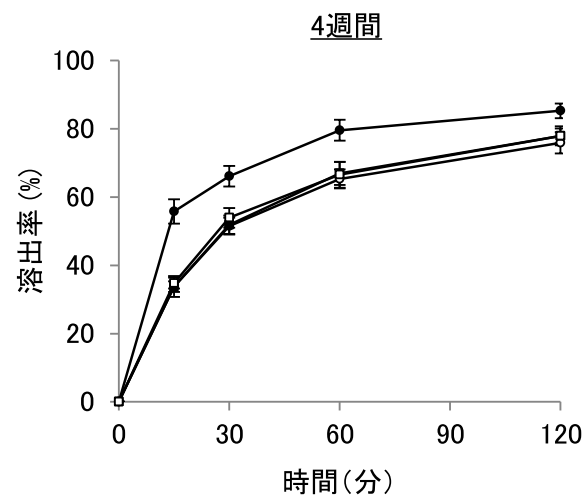

C

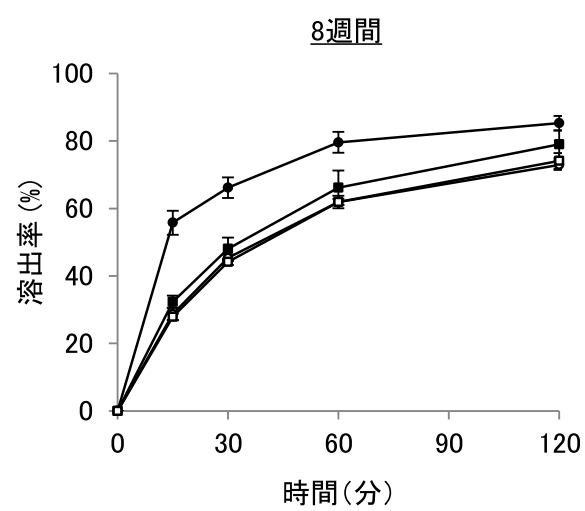

図 5 一包化保存後の酸化マグネシウム錠の溶出率 $\mathrm{A}: 1$ 週間後の溶出率, $\mathrm{B}: 4$ 週間後の溶出率, $\mathrm{C}: 8$ 週間後の 溶出率. 開封直後, $\bigcirc$ 開封直後に一包化, 1.4\%吸湿後に 一包化, $\square 4.1 \%$ 吸湿後に一包化. 全ての開封直後の溶出率は 同じ結果である. 各点は平均 \pm 標準偏差を示す.

硬度は 4 週間保存後までは開封直後および $1.4 \%$ の一包化前の吸湿ではほとんど影響は見られな かったが，4.1\%吸湿後に一包化した際には吸湿 量の増加に伴い硬度の上昇が認められた（図 4B).ささらに， 8 週間保存時にはいずれの場合も 硬度の上昇が見られた。崩壊時間は，いずれの条 件においても 1 週間後から延長していたが, $1.4 \%$ の一包化前吸湿では開封直後に一包化した場合と 
同程度の変化であったのに対し， $4.1 \%$ の一包化 前吸湿においては 4 週間保存時まではそれらより も大きな崩壊時間の延長が認められた（図 4C）. 一方， 8 週間保存時においては開封直後および $1.4 \%$ の包化前吸湿を受けた酸化マグネシウム 錠では崩壊時間が約 8 分まで延長したのに対し， 一包化前に $4.1 \%$ の吸湿を受けた際には 3 分程度 にとどまった（図 4C）.

また，溶出率はいずれの場合においても 1 週間保 存後から低下したが，一包化前の吸湿による差は生 じなかった（図 5A)，さらに，その割合は 8 週間保 存後でも 1 週間保存時と同程度であり 120 分後の溶 出率は約 10\%の低下にとどまった（図 5B）.

\section{3. ローターカセット内での酸化マグネシウム錠 の位置が吸湿に及ぼす影響（図 6)}

ローターカセット内で保存した際にカセット下 部の排出口付近の吸湿が高い傾向があったため, ローターカセットに酸化マグネシウム錠を 400 錠

A

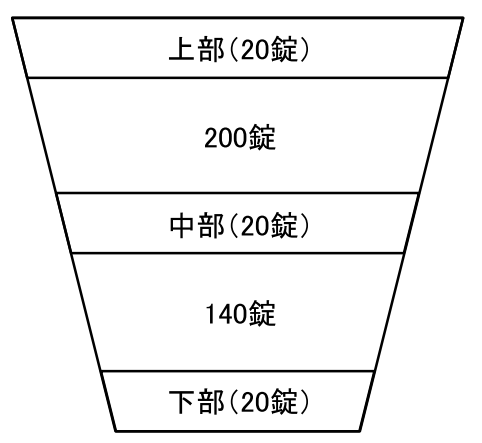

B

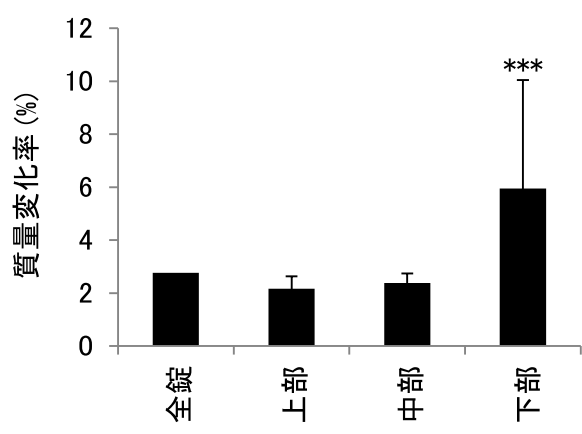

図6ローターカセット内での錠剤の位置が吸湿に 及ぼす影響

A：ローターカセットに設置した錠剤の概略図，B：質量変化 率. 各点は平均 \pm 標準偏差を示す. $* * * P<0.001 \mathrm{vs}$ ローター カセット上部および中部 (Student's $t$-test).
入れ, $75 \%$ RH の環境で 28 日間保存した際のカ セット上部, 中部, 下部での吸湿量を比較した（図 6A)。その結果, カセット上部抢よび中部の吸湿 量は全体の吸湿量と同程度であったのに対し, 排 出口に近い錠剂下部の吸湿量はそれよりも高かっ た（図6B）。

\section{考察}

本研究では，ローターカセット内での保存が吸 湿性医薬品である酸化マグネシウム錠の安定性に 及ぼす影響を調べた。酸化マグネシウム錠の添付 文書には，取り扱い上の注意として「本剤は湿気 に影響されるので，開封後はできるだけ速やかに 使用すること．また，開封後は湿気を避けて保管 すること.」と記載されている. しかし, 酸化マ グネシウム錠は一包化調剤を想定したバラ包装が 販売されていることから, 自動錠剂分包機使用時 に受ける吸湿の影響を明らかにする必要がある. これまでに, 無包装状態もしくは一包化状態の酸 化マグネシウム錠が吸湿によって受ける影響につ いては様々な報告があるが，ローターカセット内 での吸湿の影響は不明であった. ${ }^{4,5)}$ また，一包化 調剤前に受けた吸湿が一包化後の安定性に及ぼす 影響も検討されていない.

本研究により酸化マグネシウム錠をローターカ セットで 1 週間保存した際には, 湿度に依存して 質量が増加したが, 錠剤の硬度, 崩壊性および溶 出性はほとんど変化しなかった。また，吸湿によ り錠剂が大きくなることによるローターカセット 内での 2 錠の噛み込みや割れ・欠けなどの分包時 の錠剂破損掞よび摩損度の低下も認められなかっ た（図 2,3）. 従って, 酸化マグネシウム錠のロー ターカセット内での保存は, 品質にほとんど影響 を及ぼさないと考えられる。 しかし, 平均吸湿量 の 2 倍以上の吸湿を受けた錠剤もわずかに存在し ており，それらは外気に曝される可能性の高い排 出口付近の錠剂であった。ローターカセットに酸 化マグネシウム錠を 400 錠入れ，湿度 $75 \% \mathrm{RH}$ の環境で 1 カ月保存した際にも，ローターカセッ 卜下部の錠剤の吸湿量は上部および中部よりも高 かったことから, 排出口付近の錠剤は吸湿を受け 
やすいことが示唆された（図 6). しかし，排出 口付近の錠剤は他の位置に存在する錠剂よりも早 期に使用されるため，定期的に一包化調剤される 錠剤では吸湿による影響は少ないと考えられる。

ローターカセット内で 1 週間保存しても酸化マ グネシウム錠の品質にほとんど影響を及ぼさな かったが,あらかじめ吸湿させた錠剤を一包化し， 湿度 $75 \%$ RH で 1 カ月間保存した際には，一包 化前の吸湿により崩壊時間の延長が引き起こされ た（図 4C）。一方，2 力月間保存した際には，一 包化前に $4.1 \%$ の吸湿を受けた錠剤のほうが開封 直後に一包化した場合よりも崩壊時間が短かった （図 4C)。一包化前の吸湿は, 無包装状態での吸 湿であるため一包化薬よりも吸湿速度が速い。錠 凨は外側から吸湿を受けると考えられるため，錠 剂の一部分への素早い吸湿が崩壊時間に影響を及 ぼした可能性が示唆される。しかし，この現象が 酸化マグネシウム錠において一般的であるか明ら かにするためには，複数のロットおよびほかの規 格を用いた更なる解析が必要となる。しかし，い ずれの場合に打いても崩壊時間は著しく延長して いたため, 酸化マグネシウム錠を一包化する際に は，ローターカセット内での吸湿をできる限り抑 制し, 高湿度の時期には一包化薬を長期保存しな いことが重要になる.

本研究では, ローターカセット内での吸湿の抑制 には乾燥剤の使用が有効であることを示したが, 乾燥剂は長期間使用することができないため定期 的に交換する必要がある。また，上述したローター カセット内で 400 錠の酸化マグネシウム錠を保存し た際の 1 錠あたりの吸湿量は 50 錠保存した場合よ りも少なかった（結果は示してない）。これは, ロー ターカセット内の水分量が同程度であるのに対し， 錠剂数が多いため 1 錠あたりの吸湿量が減少した ためであると考えられる，従って，ローターカセッ ト内には調剤する錠剤数のみを充填することが望 ましいが，調剤後に錠剤が残存してしまう場合に は充填錠数を多くするほうが吸湿の影響が少なく なると示唆される。一方, 2 力月保存時までの溶出 率は一包化前の吸湿による影響は少なく, 錠剂の 胃内滞留時間は 30～120 分と考えられており，120 分の溶出率はいずれの条件においても開封直後の
錠剤の約 10\%の低下にとどまったことから，吸湿 が溶出性に及ぼす影響は少ないと考えられる。

酸化マグネシウムのなかでも高い崩壊性を有す るものは嚥下困難な患者にとって利点となるが, 吸湿によって崩壊し難くなった場合には服用が困 難になる恐れがある。そのため, 薬剂師をはじめ とする医療関係者は保存方法に注意するだけでは なく, 服薬指導を通して一包化した酸化マグネシ ウム錠を高湿度環境下で長期保存しないように伝 える必要がある。.以前, 我々は一包化した高吸湿 性医薬品の吸湿抑制に乾燥剤入りポリエチレン袋 中での保存が有効であることを明らかにした. ${ }^{11)}$ 従って, 一包化した酸化マグネシウム錠を乾燥剂 入りポリエチレン袋で保存することにより品質を 維持することができると考えられる，また，薬剤 師は必要に応じて処方期間の短縮を処方医に提案 することも考慮しなければならない.

以上, 本研究により酸化マグネシウム錠のロー ターカセット内での吸湿が, 一包化調剤後の安定 性に影響を及ぼすことが明らかとなった，医薬品 の一包化は薬の飲み間違いや飲み忘れを防ぐうえ で有効であり，今後，そのニーズはさらに高まる と考えられる. 本研究では酸化マグネシウム錠に ついて検討を行ったが, ほかの吸湿性が高い医薬 品についてもローターカセット内で保存した際に は吸湿が生じると考えられる。 また，ローターカ セット内で保存した医薬品は, 調剂時には品質が 変化していなくても患者宅での保存時に品質の低 下を引き起こす恐れがあるため, 慎重な扱いが必 要となる. 本研究結果が酸化マグネシウム錠だけ にとどまらず，他の吸湿性医薬品の自動錠剂分包 機での保存および調剤後の安定性の指針となるこ とを期待する.

\section{利益相反}

開示すべき利益相反はない。

\section{引用文献}

1）祖父江光広, 安倍洋子, 川村 勇, 祖父江久恵, 馬場秀明, 堀江志朗, 粉体工学会誌, コンプライ 
アンス向上と打錠障害防止を目的とした酸化マ グネシウム錠の開発 薬効薬理試験, 粉体工学会 誌, 2002, 39, 503-508.

2）祖父江光広, 安倍洋子, 猪熊博文, 上田幸則, 祖父江 久恵, 堀江史朗，コンプライアンス向上と打錠 障害防止を目的とした酸化マグネシウム錠の開 発 一製法のスケールアップと錠剂特性一, 粉体 工学会誌, 2002, 39, 509-512.

3）井上修司, 中川美幸, 馬場智子, 長南玲子, 小島 麻里, 来栖 猛, 濱武久美子, 蛭田千昭, 堀田総 一, 江尻成昭, 酸化マグネシウムの細粒剤と製剤 工夫された錠剤（マグミット® 錠）の比較 - 患 者満足度および利便性・有益性の観点から一, 日本病院薬剂師会雑誌, 2005, 41, 867-871.

4）廣澤 孝, 時岡健一, 高田啓介, 多喜川彩子, 大澤 友二, 戸田 潤, 藤井まき子, 渡辺善照, 濱野公俊, 増原慶壮, $\mathrm{MgO}$ 錠剤の安定性の評価, 医学と薬 学, 2008, 59, 67-78.

5) Oka R, Uwai K, Toyoguchi T, Shiraishi T, Nakagawa Y, Takeshita M, Stability of Magnesium Oxide Products in Single-dose Packages, Jpn J Pharm Care Sci, 2007, 33, 1013-1019.

6）長谷川浩平, 栗谷良孝, 足立充司, 新家惠子, 西井
諭司, 藤田芳一, 服薬コンプライアンスのさらな る向上と薬剤管理指導業務 - 患者の好む薬と は一, 医療薬学, 2008, 34, 800-804.

7）吉岡三郎, 北本亜紀, 金澤佐織, 岡本成史, 横田 淳子, 尾木恭子, 宮野 望, 小野川雅英, 増井 寿, 京谷庄二郎, 西岡 豊, 高知医科大学病院におけ る一包化調剂に対する外来患者意識調査と調剂 過誤に与える影響, 医療薬学, 2001, 27, 356-362.

8）「錠剤・カプセル剂の無包装状態での安定性情 報」編集委員会編, “錠剤・カプセル剂の無包装 状態での安定性情報”改訂 6 版, 医薬ジャーナ ル社, 大阪, 2009.

9）沼尻幸彦, 竹井理香, 木村聡一郎, 上田秀雄, 小林 大介, 山崎眞一, 森本雍憲, 全自動錠剂分包機 ローターカセット内の温度および湿度の予測, 医療薬学, 2007, 33, 405-410.

10）朝長文弥, 堀岡正義, 梅沢 修, 黒田 健, 紀氏 汎惠, 武信貞夫, 細田順一, 小林輝明, 長谷川満吉, 対間康憲, 松村正史, 峯沢 豊, 病院薬局の環境 衛生のあり方, 病院薬学, 1983, 9, 79-88.

11）松尾泰佑, 佐塚泰之, 高吸湿性医薬品グルコバイ ${ }^{\circledR}$ 錠の一包化調剂後の適切な保存方法の検討, 医 療薬学, 2018, 44, 83-89. 